\title{
Outdated but profitable: \\ China's approach for science and technology in the countryside and the future of the Spark Program
}

DOI: 10.32870/mycp.v11i32.354

Arturo Salazar*

\begin{abstract}
This is a study of Chinese science and technology development policies through Spark Program which was designed to encourage the companies of Chinese communities and small villages and also as a relief mechanism for poverty. In spite of the economic success of the above-mentioned program, the study sets out that in accordance with the analysis of some technological indicators, the program has not been able to raise the Asian giant's technological levels.

Key words: Spark Program, science and technology, poverty, China.

\section{Resumen}

En este trabajo se examinan las políticas chinas de fomento a la ciencia y la tecnología a través del Programa Spark, el cual es un instrumento diseñado para estimular a las empresas de comunidades y pequeños pueblos de China y también como un mecanismo de alivio a la pobreza. No obstante el éxito económico de dicho programa, el trabajo expone que de acuerdo con el análisis de algunos indicadores tecnológicos, en general éste no ha logrado elevar los niveles tecnológicos del gigante asiático.

Palabras clave: Programa Spark, ciencia y tecnología, pobreza, China.
\end{abstract}

\section{Introduction}

T $\mathrm{t}$ is impossible to understand China's economic growth in the countryside without a reference to the Spark Program (1986). Specifically created to stimulate the adoption of science and technology (S\&T) in the township and village enterprises (TVEs) and to alleviate poverty, the Spark has improved the lives of millions of households in the rural areas in the last twenty years.

* $\quad$ Profesor del Departamento de Estudios Internacionales del Pacífico, Universidad de California, San Diego 
However, when technological indicators are revised, the program's apparent success becomes questionable. This paper addresses the question of whether, in reality, the official version of the Spark program is sustainable and what are the causes, if any, of the less positive technological indicators. I argue that despite the economic success of the Spark Program, it has done very little in improving the technological level of the countryside. This paradox is due to structural factors related to the design and management of the program, as well as the incentives that it provides for exploiting its benefits. The paper suggests some strategies to surpass the former challenges, but concludes that unless the Chinese government reforms its approach to $\mathrm{S} \& \mathrm{~T}$ in the agricultural realm it is very unlikely that the level of technological development in the countryside will improve and catch up with the developed countries.

\section{"A single Spark can start a prairie fire"}

When Deng Xiaoping and the reformers planned the transformation of the economy at the end of the 1970s, they were thinking of the rural areas. The economy of China's rural population was depressed after decades serving as China's fuel for economic growth. The relaxation of controls that allowed peasants to retain their products to sell them in the private market, together with the increase in the prices of official procurement, is half of the answer for China's rural development up to mid 1990s (Naughton 2007). The other half were the township-village enterprises (TVEs) created to commercialize the agricultural production on a bigger scale. Warned by the experience in the transformation of the industrial sector, planners realized the importance of S\&T in multiplying the economic benefits of the TVEs and immediately proceeded to provide a framework for them.

On May 1985, the Ministry of Science and Technology submitted to the State Council a suggestion to "implement a batch of scientific and technological projects of quick benefit to promote rejuvenation of the regional economy" in which the Chinese proverb "A single spark can start a prairie fire" was quoted, hence came the name of Spark Program (Lo 2006). The Spark became the nation's first guided development program designed to develop the rural economy through S\&T. Soon after, on March 1986, when the Chinese government approved the implementation of the program, it was clear what kind of S\&T the Spark was intended to promote: "short, cheap and quick projects to popularize farming techniques and farm produce 
processing technologies" (Decision of the State Council on Developing the Rural Economy through S\&T, 1986: 5). Such "technologies" included: crop planting, breeding, deep processing of agricultural products, agricultural chemical industry, new agricultural equipment and rural building materials. In the years to come, only exploitation techniques for mining, fertilizers and textiles were introduced to the original list of projects supported by the Spark. From then on, the program has preserved its original content without any significant modification.

\section{The ascendant success of China's S\&T Program for the countryside}

Beginning in the 1980s, China formulated a series of general programs for research and development aimed at improving China's scientific competitiveness worldwide. As Hu and Jefferson (2004) point out, the government supported two types of programs: those that focused on supporting basic research, and those with a primary objective to promote the diffusion of applied technologies. The "Climbing" and the "863 Program" together with the National Natural Science Foundation are examples of the first group; ${ }^{1}$ whereas the "Key Projects", "Torch", "Spark", and "Dissemination" programs are part of the latter.

One of the main differences between both groups is the financial support that they receive from the government. While programs on basic research are fully financed by public funds, programs on applied technologies - Spark included - receive limited resources and are encouraged to raise funds privately. As for the Spark Program, the government appropriation in 1990s barely surpassed 5\%. Bank loans and private capital occupied the principal investment of the projects. In fact, the projects sponsored by this program immediately attained the government credit for the bank loan application. In $2000,16.8 \%$ of total investment of this program came from bank loans (Huang et. al. 2004: 10).

Precisely because of this characteristic, the Spark Program's performance is more than remarkable. According to the economic results from the TVEs and the own program, the Spark's success is unquestionable. As Table 1 shows,

1. As with the Spark Program, there is no account of any systematic studies that evaluate the effectiveness of these programs (Hu \& Jefferson 2004: 15). 
the Spark Program has achieve excellent results in every category of economic performance, and the funding and profits generated by its projects have increased consistently. Media coverage dedicated to applaud the program's achievements is abundant on the national and local levels (Cui 2001, 1996; Xiao Zhan 1998; Song 1996; Wu Xiaojun 1996). In sum, a farmer who worked for a project supported by the Spark Program saw his income increase by 300\% in average from 1986 to 2006 (Cui 2001).

Table 1

Performance of the Spark Program 1993-2005²

\begin{tabular}{|c|c|c|c|c|}
\hline & 1993 & 1996 & 2001 & 2005 \\
\hline $\begin{array}{l}\text { Coverage } \\
\text { (counties) }\end{array}$ & $80 \%$ & $83 \%$ & $85 \%$ & $90 \%$ \\
\hline $\begin{array}{l}\text { Projects } \\
\text { (accumulated) }\end{array}$ & 50,634 & 66,700 & 93,476 & 150,000 \\
\hline Total funding & U.S. $\$ 3.12$ billion & U.S. $\$ 3.5$ billion & U.S. $\$ 6$ billion & U.S. $\$ 7.1$ billion \\
\hline $\begin{array}{l}\text { Profits and taxes } \\
\text { (accumulated) }\end{array}$ & U.S. $\$ 4.7$ billion & U.S. $\$ 5.6$ billion & $\mathrm{N} / \mathrm{A}$ & $\mathrm{N} / \mathrm{A}$ \\
\hline
\end{tabular}

Source: author.

Furthermore, the TVEs included under the Spark Program had an average profit rate of $7.83 \%$ (much higher than the national average of $3.09 \%$ ) and generated, on average, 139 new jobs (Du \& Xu (1997), cited in Hu \& Jefferson 2004: 15). ${ }^{3}$ Not only did the Spark generate impressive economic results, but it was also the first recipient of funds compared to other S\&T programs. According to Table 2, the Spark was the only program whose funding reached decimal percentage points of the national GDP. Similarly, the Spark program surpassed its rivals amounting $53.83 \%$ of the total expenditure in R\&D (GERD).

2. Source: Huang et. al. (2004), Cui (2001), Song (1996), Renmin Ribao (1995).

3. Nonetheless, Hu \& Jefferson warn that "it is unclear that the study [of Du \& Xu] takes into account the non-randomness of participation in the Spark program. So the evidence presented is only suggestive" (2004:16). 
Table 2

Funding for current S\&T Programs ${ }^{4}$

\begin{tabular}{lcc}
\hline Program & Ratio of Funding to GDP & Ratio of Funding to GERD \\
\hline Key Technology R\&D Program & $0.012 \%$ & $1.18 \%$ \\
National Key Laboratories Program & $0.017 \%$ & $1.72 \%$ \\
Spark Program & $0.546 \%$ & $53.83 \%$ \\
National Science Foundation of & $0.015 \%$ & $1.43 \%$ \\
China & & \\
863 Program & $0.010 \%$ & $1.00 \%$ \\
National New Product Program & $0.002 \%$ & $0.16 \%$ \\
973 Program & $0.007 \%$ & $0.70 \%$ \\
The Innovation Fund for Small & $0.008 \%$ & $0.78 \%$ \\
Technology Based Firms & & \\
\hline \hline
\end{tabular}

Source: author.

Given the former evidence, the Spark is by far China's most successful S\&T program in economic terms. However, the projects' technological level has not been discussed so far. Where is China's countryside in terms of technological advancement? Is China's agriculture as technologically intensive as indicated by its share of GERD? A closer revision of these and other indicators is needed in order to ascertain the positive conclusions made by the Chinese government.

\section{Addressing the myth: The state of S\&T in the rural areas}

Indices of S\&T-use measured as the final product's share of total inputs coming from $\mathrm{S} \& \mathrm{~T}$ are available for certain devices and countries, but this is not the case in China. This is why the absence of literature and systematic studies that evaluate the Spark Program is not a coincidence. Lacking information related to a product's technological content creates problems for evaluation and conclusion making. However, for the purposes of this paper, I will use media and personal testimonies as proxies to measure the Spark project's technological content. Knowing that my analysis is merely interpretative, my hypothesis and conclusions might not be precise; nevertheless one thing is for sure: the Chinese approach of "short, cheap and quick science" has remained

4. Data for 2000 includes state and private funding. Source: Huang et al. (2004: 12). 
unchanged since 1986 and so it has shaped the level of technology of all the Spark projects approved. ${ }^{5}$

Looking at two indicators of technological intensiveness in China's countryside, the "unquestionable success" of the Spark Program seems to be overestimated. A national census in 2003 showed that only 5\% of the rural labour population had received some type of systematic technological training, and $90 \%$ of about 900 million Chinese farmers have never received high school education (Xinhua 15 Oct 06). This condition of "initial disadvantage" is reflected by the top leaders' acknowledgment of what constituted the level of technology in rural China previous to the reform:

[The Spark Program] is a great invention made by the country's science and technology circle, and also a great tool to help farmers overcome superstition and poverty and march toward prosperity by relying on science and technology (Jiang Zemin, cited in Xinhua, 27 Sep 96).

Given the medieval state of technological development reflected in the prevalence of superstition among farmers, it is not surprising that the Spark is highly valued by the Chinese government. Another set of evidence of the program's failure to increase S\&T in the projects approved include: the decline in factor productivity of the more intensively cultivated cropping soils, the need of solutions for the new pests and pathogens, and the null marketability of many of China's agricultural products (IDRC 1997: 247). I call this evidence "second generation problems" because as the IDRC states "the gains from the application of the original Spark technologies have been already achieved" and these challenges respond to the outdated status of such technologies. Otherwise, why would they emerge? The Chinese leadership is conscious of these problems but refuses to acknowledge the outdated condition of the Spark technologies:

At the same time, however, we should also be aware of the need to solve problems in the following aspects if we are to bring about a new leap forward, considerable

5. As early as 2006 the 10 -year plan for the Spark Program considered the following as priority areas: farming projects, water-saving irrigation, soil fertilization, livestock breeding projects, technologies to store and process grains, new fertilizers, updated equipment for agro-products processing, textile and light industry, building materials, and mineral resources exploration (Cui 1996). 
development, and an upswing to the "Spark Plan": First, though an increase has been registered in the amount of inputs into single projects of the "Spark Plan", the method of developing single techniques, promoting single enterprises, and bringing up individual demonstration rural households can no longer satisfy the demands of the present new development trend. The "Spark Plan" needs to explore a new road for the development of rural economies of scale. The "Spark Plan" also needs to enhance its management and improve its ability to provide leading guidance. The present new situation requires the "Spark Plan" to make new leaps forward and new contributions to China's rural economic development (Investigation and Study Office under the General Office of the CPC Central Committee, Renmin Ribao, 17 Oct 96).

Additionally, the Spark techniques' low technological intensiveness is evident in the products displayed at the high technology fairs that the Chinese government proudly promotes as "samples of glorious agro-techniques". According to di Capua (1998):

The fairs I attended were highly eclectic in nature, with an atmosphere reminiscent of what county fairs must have been like in rural America perhaps 75 years ago. Exhibits included colorful minerals and chemicals in tear-drop-shaped vials; machines to fill and seal snack food packages; country-living conveniences like portable showers and solar water heaters; coal-burning stoves and composting toilets; patent virility enhancers and pseudo-science medical devices; and even fetal sonogram franchises.

Government officials and policy pronouncements now appear to publicly acknowledge that state-directed infusions of capital and technology have failed to yield the hoped-for rise in product quality and profitability.

Finally, the outdated technology of the Spark Program is reflected in the rising complaints about the excessive pollution generated by its techniques. Because the TVEs under the Spark are concentrated in highly polluting industries, in the traditional sense, (coal mining, cement making, pulp and paper production, brick making, and fertilizers) it creates waste that is less visible, more difficult to monitor, and can be very harmful to human health and the environment (IDRC 1997: 240). In this regard, the IDRC's conclusion is quite revealing:

The impression gained by the Mission is that, as a result of the establishment of thousands of TVEs throughout the rural areas, largely through the Spark Program - the environmental challenge to the S\&T system is considerably greater 
now than at the beginning of the decade of reform. S\&T reforms have created an environmental moving target for themselves, necessitating further reform in S\&T priorities, system renewal, and performance. The challenge is to find an appropriate Chinese package of S\&T initiatives to deal with this environmental problem (IDRC \& The State Science and Technology Commission 1997: 242).

Given the lack of systematic records available to the public, all these examples may not account as serious scientific indicators of technological scarcity in the projects carried out by the Spark Program. Moreover, since the evidence presented is isolated data, the conclusions I derive in the following section must be read carefully to prevent inaccurate generalizations. However, judging by the testimonies outlined above, the Spark is far from its optimal condition. The release of systematic technological data from the program, as well as further research in this area, will be critical to move away from simple estimations and will open the window to study what apparently is the biggest S\&T program for the rural areas in the world.

\section{Squaring the circle: Why would more money lead to poor technology?}

Given the available information, it seems obvious that there is a contradiction between the Spark's excellent economic results and its low technological achievements. In order to understand the former oddity, a supply and demand analysis is useless given that theoretically better technology would raise investment. But this is not the case of the Spark Program. For this reason, I will argue that this paradoxical situation is the result of three self-reinforcing factors: the regime's obsession with quick returns, the program's approach of "cheap" technology for the countryside, and the institutional framework that allow for the program's inappropriate use.

\section{The importance of quick returns}

Regarding the increasing funds raised by the Spark Program, it must be read in light of the Chinese tradition to pursue incremental targets. Characteristic of this Chinese feature are the 5-year plans to develop the economy, the same in the Mao as in the reform era. The Spark Program is not the exemption. In 1986 and 1996 the Chinese government outlined the targets to be accomplished in the following 10 years. But the target's rationality is what matters; 
it serves as a means to secure quick returns that can legitimize the regime internally and externally, although the main driver of such increase might be employment creation in the countryside at a time when Chinese farmers' economy was very depressed. Whether or not the incremental funding for the Spark Program was a pure economic policy to alleviate poverty, the fact that political considerations also intervened in raising funds is supported by the following statement:

Agriculture is the basis for the national economy, and farmers account for 80 percent of China's total population. Agriculture has become the nation's top problem concerning China's economic development and social stability (Han Deqian, Vice-Minister of the State Commission for Science and Technology, cited in Xinhua, 12 Sep 96).

Social unrest in the countryside is a potential threat to the regime's continuity that the leaders consciously weighed when the Spark was approved. Therefore, it is not surprising that regardless of the technological level of the Spark projects, funds kept rising uninterruptedly over time. Although it could be argued that the former is not a feasible argument because the government participation in the program's total funding is very low (hardly $5 \%$, Huang et al. 2004: 10), the truth is that bank loans - which are the bulk of the projects' funding - are available immediately after the government's approval. This is why when it comes to justifications, the Chinese government can defend the program easily and openly acknowledge what is expected from it:

Whether or not we can succeed in invigorating agriculture by applying scientific and technological advances depend, to a considerable extent, on the protection and support of the government, yet a large input by the government is impossible. Can we attain high economic returns with a small government input? The practice of the Spark Program has showed us clearly that it is totally possible for us to attain a high economic return on the basis of a small government input (Investigation and Study Office under the General Office of the CPC Central Committee, Renmin Ribao, 17 Oct 96).

The former statement makes clear what the hypothesis states: the government is more concerned with the issue of funds than with the proper technologies carried out by the Spark; and secondly, it openly portrays what are the important indicators for the Chinese leadership: economic returns, not technological advancements. 


\section{Cheap approach for S\&T}

As a result of the former, the "second generation problems" are a natural by-product given the preservation of the "short, cheap and quick" approach for S\&T in the rural areas. The null existence of technologies to provide organizational improvements in the TVEs, or to introduce marketing solutions for new products, reflects the unbalance between production and postproduction activities supported by the Spark Program. A broader approach that considers these challenges is urgently needed not only to respond to the growing value-adding food-processing industries, but also to put an end to the pollution problem generated by the outdated technology. At the end of the day, the "second generation problems" should not surprise us at all since the Spark Program clearly establishes the type of disposable technologies, and anything outside of the list will not be supported.

But there are other factors related to the management of the program that impede an optimal use of technology. While there are offices of Spark Program at the four levels of the State (national, provincial, prefecture and county), there is only one agency responsible to transfer technology throughout the nation, the National Agricultural Technical Extension Centre. The consequence is quite evident: technology never reaches the distant areas. Another problem is the complex structure of the agricultural research system. The research institutes operate independently and the lack of coordination leads to unnecessary duplication and competition for resources. Little attention is put on output orientation and post-production problems, including post harvest issues and those associated with processing the products of the production systems (IDRC \& The State Science and Technology Commission 1997: 265).

The critical level of $S \& \mathrm{~T}$ in the projects of the Spark Program is, therefore, a function of two endemic problems: on the one hand it is constrained by a cheap approach, and on the other hand its manage-

The critical level of s\&t in the projects of the Spark Program is, therefore, a function of two endemic problems: on the one hand it is constrained by a cheap approach, and on the other hand its management depends on a disorganized structure. 
ment depends on a disorganized structure. These obstacles will be the most difficult to overcome in the future due to the political implications of losing an inexpensive employment making machine and the costs associated to a bureaucratic restructuring.

\section{A realty opportunity}

Although there is little documented support for this hypothesis, its logic is persuasive. The Spark Program has become the excuse for enclosure by unscrupulous land developers that take advantage of the land ownership granted to Spark projects. As Lo states:

When one travels in China, placards or boards displaying Spark Program and a big piece of land encircled are always seen. After all, the most valuable thing of all Spark Programs in China perhaps is the piece of land concerned. After being put aside for three, five, eight or even ten years, God knows how many people will turn out to be billionaires (2006: 6).

Given this situation, the paradox that we try to explain finally seems to have a logical explanation: the demand and supply forces cannot explain how increasing funds are leading to decreasing levels of technology in the countryside, because the demand is artificially inflated by the real-estate industry that sees in the Spark Program a formidable opportunity to own land at a very cheap price (they just have to apply for a project and follow it for a couple of years without any incentive to demand technological improvements). As Lo states, nobody knows with certainty how many Spark projects are now waiting to close and get the benefits they are entitled to. In this scenario, the prospects for an update of the Spark Program are less positive and will be conditional on filling the caveats and developing monitoring bodies to detect abuses from land speculators.

\section{Summary}

Twenty years after its creation, the Spark Program shows two different stories: on the one hand, it is successful in raising funds and profits, but at the same time it has not increased the technological level of the countryside. As a result, the TVEs and projects under the Spark cannot deal with "second 
generation problems" that detain its further development. The poor technological content of Spark projects is primarily the result of an old framework that prioritizes "short, cheap and quick" techniques for 900 million farmers that still use superstition to perform their activities. This "cheap" approach is conveniently preserved by the Chinese government for the purpose of employment creation and legitimization. However, the opportunities for land ownership provided by the Spark program seem to exert a considerable influence in the technological lag of the rural areas, although it is not yet systematically tested.

In the mean time, as long as the Chinese government preserve the outdated approach for S\&T in the agricultural realm, it is very unlikely that the level of technological development in the countryside will improve and catch up with the developed countries. At the same time, if China's agricultural research is to become a major player in the world's advanced S\&T, it will be necessary to reorganize the structure and management of existing agricultural research and enhance collaboration of the national research institutes in order to prevent duplication. Not surprising, Lo's conclusion is that the Spark's S\&T are false, big and empty words in today's China's villages (2006: 7).

In the future, scholarship on the Spark Program will be extremely important in order to address its performance with serious scientific indicators, instead of blurry interpretations. So long as the Chinese leadership sees the Spark Program more as a poverty alleviator than as a serious investment in technology, criticisms that researchers have for other S\&T programs can be adapted and repeated for the Spark: while the other programs are criticized for focusing more on development than in research, the Spark can be blamed for being more a remedy than a real solution for the rural technological lag. The future of the Spark Program will depend on that critical reform.

\section{References}

Cстv, Agriculture Minister Du Answer Press Questions on 'Three Rural Issues', 10 Mar, 2005.

China Daily, "Ministry of sт Source Says Expanding Bilateral, Multilateral Programs", 05 Oct, 2004.

Dahlman, Carl J., and Jean-Eric Aubert, China and the Knowledge Economy: Seizing the 21 ${ }^{\text {st }}$ Century, The World Bank, Washington DC, 2001. 
Di Capua, Marco, "Technology Innovation in China”, The Bridge, Vol. 28, No. 2, Summer, 1998.

Dinghuan, Shi, and Ted Y. Li, "Torch Program - Birthed in Texas, Grown Up in China, Returning to Texas/Mexico: An Entrepreneurship Creation Program for the Success of Chinese High Tech Industry", The Texas Lyceum Journal, April, 2006.

Gang, Zhao, "Broad Prospects for Sino-African Cooperation in Science, Technology (Sino-African Friendship)”, Renmin Ribao, 30 Aug, 2006.

Guifa, Zhu, and J. Davidson Frame, "Technology transfer within China", The Journal of Technology Transfer, Vol. 11, No. 2, March, 1987, pp. 29-42.

Hu, Albert G. Z., and Gary H. Jefferson, Science and Technology in China, paper presented to the Conference China's Economic Transition: Origins, Mechanisms, and Consequences, Pittsburgh, 5-7 November, 2004.

Huang, Celeste Amorim, Mark Spinoglio, Borges Gouveia, and Augusto Medina, "Organization, programme and structure: an analysis of the Chinese innovation policy framework", R\&D Management, Vol. 34, Issue 4, 2004, pp. 367-387.

IDRC, andThe State Science and Technology Commission, "Agricultural Research and Rural Development", A Decade of Reform. Science and Technology Policy in China, Chapter 11, IDRC, Toronto, 1997, pp. 240-270.

Jiabao, Wen, "Spark Program: Successful Way of Sending Science, Technology to Rural Areas", Renmin Ribao, 06 Mar, 1996.

Jian, Song, "It Is Necessary To Strengthen the Transformation of Scientific and Technological Achievements so as to Implement the Policy of Reviving China through Science and Education", Kexuexue, No. 9, 01 Sep, 1996a, pp. 16-21.

- - "Always Bear in Mind the People's Trust-Written for the 10th Anniversary of the Spark Plan", Renmin Ribao, 17 Oct, 1996b, p. 5.

Jie, Qin, “Jiang Zemin Praises National Farm Technology Program”, Xinhua, 27 Sep, 1996a.

_- , "Meeting Held on Spark Program for Spreading Technology", Xinhua, 25 Sep, 1996b.

Jingyong, Zhang, "China Will Carry out an Action to Advance the Spark Plan to the Western Regions”, Xinhua, 22 Aug, 2001.

Jinsheng, Zhang, and Han Zhenjun, "20 Years of Reform: Growth of China's S\&T", Xinhua, 03 Oct, 1998.

Ning, Cui, “Spark Outlines Development Plan”, China Daily, 26 Sep, 1996b. 
_- "Spark Scheme Ignites Interest", China Daily, 13 Sep, 1996a.

_- "Spark To Fuel Tibet's Economic Development", China Daily, 27 Sep, 1996c.

_-, "Zhu Lilan: New Policies To Spark Technological Innovation", China Daily, 09 Aug, 1999.

- - "China Daily staff: "China's Wind of Change Blows West", China Daily, 04 Aug, 2000.

_-, "Funds Magnified To Spark Agricultural Economy", China Daily, 29 Sep, 2001.

Ping, Lo, "Cool-off From Fanaticism With Science-Technology Patriotism: Story Behind Hu Jintao's Inclination Toward Us, Counting on Bill Gates", HK Journal, 01 Aug, 2006.

Renjian, Tang, "Radically Raise China's Agricultural Competitiveness - General Idea on How China's Agriculture Should Deal With wTo", Nongye Jingji Wenti, 23 Jan, 2001.

Ribao, Renmin, A Successful Way for Integrating Science and Technology With the Rural Economy, 23 Mar, 1995, p. 5.

- - Make New Contribution to Development of Rural Economy-Warmly Congratulating 10th Anniversary of Implementation of the 'Spark Plan', 17 Oct, 1996, p. 1.

- - Enhancing Autonomous Innovation Capabilities and Striving To Build a Nation of Innovation - Excerpts from Statements Made by Representatives to the National Science and Technology Conference, 18 Jan, 2006, pp. 11-12.

Seong, Somi, Steven Popper, and Kungang Zheng, Strategic Choices in Science and Technology: Korea in the Era of a Rising China, Rand Corp, Santa Monica, 2005.

Shangxi, Liu, "The Peasant 'State of Employment': The Decisive Force Determining the Success or Failure of China's Reform and Development", Zhongguo Jingji Shibao, 30 Jun, 2006.

Xiaojun, Wu, “Farmers' Benefits from ‘Spark Program' Noted”, Xinhua, 23 Sep, 1996.

Xiaomeng, Hu, “cyl Meeting To Spread Science in Rural Areas”, Xinhua, 20 May, 1998.

Xinhua, Spark Program Spurs Rural Economy in Shaanxi, 28 Mar, 1996a.

-_, Plan for Promoting Agriculture Successful in Jiangsu, 21 Aug, 1996b.

- - Overseas Investment in Spark Program Projects Welcomed, 12 Sep, 1996c. 
- - Spark Program to Receive Emphasis in West Region, 12 Sep, 1996d.

- - Spark Program' Achievements Fair Opens in Beijing, 24 Sep, 1996e.

- - Scientists Urged to Promote Agro-Science Research, 27 Sep, $1996 \mathrm{f}$.

—-, Spark Program Benefits Sichuan Farmers, 8 Mar, 1998.

- - China to Put More Funds toward Implementation of 'Spark Program' for Rural Areas, 28 Feb, 2001a.

- - Agricultural Science and Technology Development Plan 2001-2010, 23 May, 2001b.

- - China's Technology Ministry to Help Train Farmers in Modern Methods, 30 Jul, 2003.

- - O Outline of Action Plan for Improving All People's Science Quality, 20 Mar, 2006a.

- - China's Rural Technology 'Spark Program' Covers Over 90\% of PRC Counties, 15 Oct, 2006b.

Zhan, Xiao, "Spark Plan Ignites Southern Economy", China Daily, 22 Feb, 1998, p. 5.

Zweig, D., "Rural industry: Constraining the leading growth sector in China's economy", China's Economic Dilemmas in the 1990s: The Problems of Reforms, Modernization, and Interdependence, M. E. Sharpe, New York, 1992.

Web pages

http://us.tom.com/english/1314.htm.

http://www.chinese-embassy.org.uk/eng/kjjl/t27121.htm.

http://www.acca21.org.cn/ppc21n1-11a.html. 